\title{
Venezuela 2016: The Year of Living Dangerously
}

\author{
Venezuela 2016: El año de vivir peligrosamente
}

\section{BARRY CANNON}

Maynooth University, Ireland

\section{JOHN BROWN}

Maynooth University, Ireland

\begin{abstract}
This article outlines the deepening political, social and economic crisis facing Venezuela. Overall, we argue that both government and opposition must take responsibility for the present crisis as both have failed to offer coherent policy responses to the problems facing the country. The government has failed to address the crisis with sufficient rigor, and seems more concerned with maintaining power, while the opposition MUD continues to offer the removal of the government as its sole solution to the crisis. Yet its policy proposals are poorly developed and do not offer long-term solutions to the country's problems. Finally, we suggest that the continuation of the Vatican/UNASUR-sponsored dialogue is the best way for Venezuela to advance if it wishes to restore economic and social stability and reduce political tension.
\end{abstract}

Key words: Venezuela, crisis, Maduro, MUD, dialogue

\section{RESUMEN}

Este artículo esboza la profundización de la crisis política, social y económica que enfrenta Venezuela. En general, argumentamos que tanto el gobierno como la oposición deben asumir la responsabilidad de la crisis actual, ya que ambos han fracasado en ofrecer respuestas políticas coherentes a los problemas que enfrenta el país. El gobierno no ha logrado abordar la crisis con suficiente rigor, y parece estar más preocupado por mantener el poder, mientras que la oposición MUD sigue ofreciendo la eliminación del gobierno como su única solución a la crisis. Sin embargo, sus propuestas de política están poco desarrolladas y no ofrecen soluciones a largo plazo a los problemas del país. Por último, sugerimos que la continuación del diálogo patrocinado por el Vaticano / UNASUR es la mejor vía para que Venezuela avance si desea restablecer la estabilidad económica y social y reducir la tensión política.

Palabras clave: Venezuela, crisis, Maduro, MUD, dialogo 


\section{INTRODUCTION}

Successive annual reviews of Venezuela in this journal have tracked the ongoing political crisis in the country due to the constant confrontations between the ruling PSUV (Partido Socialista Unida de Venezuela) and the Opposition MUD coalition (Mesa de la Unidad Democrática). Nevertheless, Cyr (2013), in her review, concludes that Chávez's revolutionary project would likely outlast his time in office, due to ambivalent or positive public attitudes to government policies and the lack of a clearly defined alternative from the opposition. However, with Chávez's death in March 2013, she raises concerns (Cyr 2013: 387) regarding his successor Nicolás Maduro's ability to hold the myriad opposition and chavista forces in check as Chávez had succeeded in doing, after the former had narrowly defeated Henrique Capriles Radonski of the Primero Justicia (PJ) party (representing the MUD) in the April 2013 presidential elections. Maduro's slim majority (a mere 1.5 per cent) was contested, with U.S. support, by Capriles and the MUD, leading to violent opposition-led protests (Hetland 2016, 17 August: $8)$.

While these eventually abated, a fresh wave of protests seeking Maduro's removal erupted in early 2014 following the ruling PSUV's strong showing in municipal elections in December 2013 (Hetland 2016, 17 August: 9). Maduro survived these protests, which resulted in the deaths of 43 people, including opposition and government supporters along with members of the security forces. Presciently, both Cyr (2013) and Sagarzazu (2014), in their respective yearly reviews for the RCP, noted that the MUD had made considerable electoral advances, losing key elections by small margins and beating the PSUV in areas where before Chávez had won easily. This tendency came to spectacular fruition in the December 2015 parliamentary elections when the PSUV was soundly beaten by the MUD, which gained a two-thirds supermajority in the National Assembly (AN) - the first time the opposition had achieved such a position since Hugo Chávez came to power in 1999. This resounding majority would allow the opposition-controlled legislature to change some fundamental laws and even aim for the removal of Maduro. In this deeply polarized scenario, with the PSUV controlling the other four of Venezuela's five state "powers" (executive, judiciary, electoral and citizens' powers), 2016 has witnessed a deepening of the political impasse. The year was thus characterized by a variety of actions on the part of both government and opposition aimed at neutralizing, preventing or reversing the actions of the other, most notably opposition attempts to remove Maduro from power and government reactions.

But while Cyr (2013) and Sagarzazu (2014) describe a country mired in an intractable political crisis, Sánchez Urribarrí (2016) shows how this had escalated into a comprehensive socio-economic crisis. The overwhelming nature of this crisis has put the PSUV's hold on power even more in doubt. In this article we show how 2016 was marked by the continuance of the socio-economic crisis described by Sánchez Urribarrí (2016), characterized by a continued economic 
slump, currency exchange difficulties, very high inflation, continued shortages of a wide variety of goods including food and medicines, increasing poverty, and high levels of violence. This socio-economic crisis has been accompanied by continued political uncertainly, opposition-led protests, and a worsening regional and international context for the Bolivarian government.

The article will look at each of these issues in turn. Following an examination of the contours of the economic and social crisis in Venezuela, as well as its position in the international context, we suggest that not only the government but also the opposition must take responsibility for creating, perpetuating and worsening the crisis by failing to offer coherent policy responses to the problems facing the country. As such, we examine the government's reaction to the crisis, first providing some background as to how it has managed it so far, and then looking at particular policy initiatives from this year, reaction to these, and personnel changes within government. We suggest that Maduro has surrounded himself with personnel who face high exit costs should the PSUV lose power, thereby ensuring their support for his remaining in office. We will then review the actions of the MUD regarding the crisis, both in terms of their declared strategies and some of the specific laws which they attempted to enact to resolve it. Most notable here is the MUD's belief that the route to resolving the crisis is through the removal of the government. This belief, and the corresponding multi-layered strategy set out in the opposition's Hoja de Ruta Democrática of March 2016, led to its doomed attempt to initiate a recall referendum against President Maduro. We will also examine some key policies that it attempted to enact in the AN, most notably its Amnesty Law and Housing Law, and how both of these only contributed to a greater sense of polarization rather than helping to resolve pressing problems. Finally, we will review the national dialogue which took place under the auspices of UNASUR (Unión de Naciones Suramericanas) and the Vatican, and argue that this is the only feasible way for Venezuela to advance if it wishes to restore economic and social stability and reduce political tension. Let U.S. begin then with the economic and social situation in the country in 2016.

\section{ECONOMY AND SOCIETY}

Santos (2017: 61) lays out the country's precarious economic situation in stark terms: crude oil, which accounts for around 90 percent of Venezuela's exports, making it the country's principal hard currency earner, descended from US\$88 a barrel in 2015 to \$34 in 2016, more than halving national income in one year alone. The IMF reported inflation at 720 per cent, with food inflation peaking at 1,400 in 2016 (Santos 2017: 61). Foreign debt repayments averaged about US\$10 billion per year, and capital flight is estimated at US $\$ 23$ billion between 2003 and 2013. Both latter phenomena draw scarce dollars away from paying for food imports, with Venezuela having little domestic food production capacity to replace it. According to Hetland (2016, 17 August) there was a 40 percent 
drop in imports in the first half of 2016, which represents a 60 percent drop since 2012. As a result, food and shortages of other vital goods continued, with an estimated 80 percent scarcity index (Hetland 2016, 17 August). While food is available on the unregulated market, Venezuelans are finding it increasingly difficult to afford the high prices there (Santos 2017: 61).

Poverty, Santos (2017: 58) states, is at 75 percent, citing a figure from work by Venezuelan academic and opposition activist, Luis Pedro España and colleagues, effectively wiping out any gains made during the Chávez period. Moreover, the homicide rates continues to be among the highest globally, with Caracas among the most violent cities in the world and seven other Venezuelan cities in the top 50 (Santos 2017). Though Santos (2017) admits his figures are "highly imperfect estimations" from private sources, the Venezuelan government has simply stopped releasing many official statistics. By contrast, what governmental statistics have been published paint a far rosier picture (INE 2017), pegging household income poverty at around 33 per cent for the first trimester of 2015 (compared to 29.4 per cent in the first trimester of 2014), estimating inequality at Gini index 0.381 for 2015, a slight reduction from 0.409 in 2013 and one of the lowest in the region, and indicating an average rise in inflation of almost 122 percent for 2015, with food inflation at almost 219 per cent (INE 2017).

\section{NATIONAL POLITICS}

National politics continued to be characterized by extreme polarization, despite a few fitful and unsuccessful attempts at negotiations, brokered by the Vatican and others (see below). ${ }^{1}$

The year began with the arrival of the opposition majority to the $\mathrm{AN}$, which was initially an MUD supermajority (i.e. two thirds of the unicameral chamber) that would have been sufficiently large to have allowed them to change some fundamental laws. The officialist-controlled Venezuelan Supreme Court (TSJ) reduced this by three deputies, however, due to irregularities in their elections, which lowered the MUD's majority below supermajority status. This prompted the AN to unilaterally reincorporate the suspended deputies in July, leading the TSJ to "declare Congress illegitimate," effectively neutering that body and any legislation it may have passed. While the three congress members eventually resigned their seats in November on the promise of fresh elections (Reuters 2016, 16 November), AN actions still remain without any legal effect and the promised elections have not transpired.

At the end of February, the MUD announced an agreed strategy to remove Maduro from power consisting of four elements: resignation, amendment to the Constitution, removal for abandonment of his post, and a recall referendum 
(see below). Of these strategies, only the recall referendum process advanced in any meaningful way, and it would dominate politics until October, when it was finally abandoned. The recall process was activated by the MUD with the Venezuelan National Electoral Council (CNE) on 9 March 2016, over two months after the new AN was installed. The process commenced at the end of April, with the collection of signatures of one percent of the national population in support of the referendum. The government-controlled CNE, however, found 600,000 ,of the 1,957,779 signatures collected invalid (or over 25 percent), which meant that this stage of the process was not completed until 24 August.

The next step for the opposition was to collect the signatures of 20 per cent of registered voters, a process that required completion by the end of October, with signatures approved by the end of November if the referendum itself was to be held by the end of the year. This timing was important as a referendum victory before year's end would have meant the removal of Maduro and new elections, which the opposition would probably win. If not, Maduro's vice president would replace him, making the whole process much less appealing, if not meaningless, from the MUD's point of view. Yet, unexpectedly, in October, the CNE found 53,658 irregular signatures, effectively suspending the entire process indefinitely. Additionally, the CNE had earlier announced the postponement of the regional and municipal elections due that December until an undetermined date in early 2017. With these moves, plus a legal prohibition on a number of MUD politicians including, including the governor of Miranda stat and presidential candidate,Henrique Capriles, the National Assembly declared Venezuela in a coup d'état situation and requested international help. This was not long in coming, when the Secretary General of the Organization of American States (OAS), Luis Almagro, called for the Inter-American Democratic Charter to be invoked against Venezuela-as he had previously attempted but failed to do in May - a process that could lead to Venezuela's suspension from that organization.

The suspension of the recall referendum process led to a period of intense activity both within Venezuela and outside the country. In Venezuela, a special session of the AN was held on 23 October, calling for outside intervention from key international organizations such as the OAS. A variety of demonstrations were held and on 28 October, including a general strike that was seen as only partly successful. The AN also began a process of putting Maduro on "trial" for abandonment of his post, as he had left the country shortly after the termination of the recall process. These events and the grim social statistics cited above were depicted in the international media in apocalyptic terms. ${ }^{2}$ Domestic turbulence coincided with stark political realignment elsewhere, which would shift Venezuela's balance of power in the international arena. Two of the most

\footnotetext{
"Venezuela's downward spiral," declared the New York Times (2016, 17 May) in an Editorial; "Venezuela on the brink" echoed The Guardian (Watts, 2016, 11 October); "Venezuela is lurching closer and closer to chaos," opined the Washington Post (2016, 26 December); with El País in Madrid quite simply declaring "Chaos in Venezuela" (2016, 20 December). These are just some examples.
} 
geopolitically important countries in Latin America, Argentina and Brazil, turned sharply to the ideological right in 2016, with the elections of Mauricio Macri in the former and the installation of Michel Temer as President in the latter, after a questionable impeachment process involving PT President Dilma Rousseff. In September, the founding members of Mercosur (Argentina, Brazil, Paraguay and Uruguay) agreed that Venezuela would not assume the pro tempore presidency of the bloc, and by early December Venezuela had been suspended from the organization. The presidency passed to Argentina (Aljazeera 2016, 3 November) despite Venezuela's energetic protestations (Boothroyd-Rojas 2016, 16 September). Meanwhile, the Secretary General of the OAS, Luis Almagro, continued to seek the application of the Democratic Charter against Venezuela, declaring in August that democracy in Venezuela had "ended" (BBC Mundo 2016, 23 August). Finally, with the election of property tycoon and reality TV star Donald J. Trump of the Republican Party as President of the United States in November, and Republican domination of both Houses of Congress, most analysts expect a hardening that country's position towards Venezuela (Gill 2016, 29 December; Woody 2016, 19 December).

Venezuela fared better with UNASUR, however, despite the changes in government in these key countries. In 2016, UNASUR was fundamental in facilitating dialogue between the PSUV executive and the MUD-controlled National Assembly, and its Secretary General, Colombian Ernesto Samper, insisted on the legitimacy of the Venezuelan state institutions and of Maduro as the country's legitimate President (Zuzunaga Ruiz 2016, 27 October). Similarly, as Timothy Gill (2016) argues, the Venezuelan government retains regional allies in Cuba, Bolivia, Ecuador, and Nicaragua, and can still rely on support from Russia and China (Gill 2017, 12 January). Hence, while the international context for the country has changed quite radically in 2016, it still retains some external support in international fora.

\section{GOVERNMENT RESPONSE TO CRISIS}

Before turning to the government's response to the crisis detailed above, it is first necessary to critically review the origins of the crisis and the role the government has played in its development. On the government's side, it blames both the domestic opposition and the U.S. for perpetrating economic warfare as the root cause of the crisis. Firstly, private producers opposed to the government have engaged in hoarding of food and basic goods, particularly in periods before elections (Hetland 2016, 17 August). Secondly, the U.S. government has fuelled the crisis by engaging in sanctions of high-ranking government officials, citing the Obama administration's qualification of Venezuela as a national security threat to the United States. These sanctions discourage European and U.S. banks and investors from doing business in the country "at a time when Venezuela is in desperate need of dollars but is prevented from gaining access to them by Washington" (Hetland 2016, 17 August). Pro-government sources 
have drawn parallels between the economic war in Venezuela and U.S. efforts to topple Allende's government in Chile in the 1970s, when President Nixon and Secretary of State Kissinger sought to "make the economy scream" (Hetland 2016, 17 August).

Yet many seasoned observers question the government's claims regarding economic warfare as the principle cause of the crisis, suggesting it is but one of the factors behind the current crisis (Hetland 2016, August). According to these experts, the single greatest cause of Venezuela's economic meltdown is mismanagement of its currency (Velasco 2016, 25 October; Hetland 2016, 17 August; Weisbrot 2016, 23 October; Buxton 2016). While currency manipulation was first undertaken as an emergency response to the oil industry strike of 2002, by 2016 it had become a byzantine three-tiered currency control system: the lower official rate of 10:1 (bolivares to dollars) applies to "essential imports"; a second official rate for non-essential imports known as DiCom, rising via a "managed float" from 200 to 697: 1 at the time of writing; and finally, a fluctuating black-market rate which currently stands at 4,229:1. The enormous gulf in rates creates serious incentives for corruption whereby businesses and state/military officials with access to dollars at the lower official rate can then resell them at black market rates, making enormous profits (Grandin 2016, 16 December; Hetland 2016, 17 August). The outcome is a shortage of dollars for food imports, lengthy queues for the little food that is available, and a greatly inflated black market for those same goods. As Velasco (2016, 25 October) notes, the oil boom "simultaneously masked and fed corruption as dollars were plentiful. But when dollars became scarce as oil prices plummeted, the breach no longer held."

So how has the government responded to this escalating crisis? In February, the government increased gasoline prices for the first time in 20 years by over $6000 \%$ (Pourcelot 2016, 10 March), a move which was regarded as an unfortunate but necessary step in the right direction. In March, it devalued the protected Bolivar Fuerte (BF) from a rate of 6.3:1 to 10:1 (bolivares to dollars) and introduced the floating official DiCom rate. This latter adjustment has been largely unsuccessful, as "the vast majority of the government's dollars are given away at the official rate of 10, and so there is very little to supply the DiCOM market" (Weisbrot 2016, 4 May). In June a specially commissioned UNASUR team of experts, many of them (such as Weisbrot) identifying with the left, presented a comprehensive set of proposals to the government to help manage the crisis (Emersberger 2016, 19 July). Among the recommendations involving monetary policy were an immediate end to the tiered currency system and the free floating of the BF on the markets, a lifting of price controls and of all energy subsidies (not just gasoline), with direct government subsidies to consumers to soften the blow, and the indexing of all salaries to the monthly inflation rate until inflation stabilizes. Additional recommendations included the selling of all non-strategic assets, a tax on financial transactions, wealth taxes, and assistance for the informal employment sector which developed under the present crisis (such as the reselling of price-controlled goods) (Emersberger 2016, 19 July). The 
government declined to adopt any of the UNASUR experts' recommendations, making it one of "the most astonishingly static governments Latin America has seen for many years" (Buxton 2016: 15).

There are a number of reasons for this inactivity. First, many in the government saw the UNASUR proposed reforms as a "paquetazo" resembling IMF neoliberal reforms of the past (Weisbrot 2016, 23 October). This problem is particularly acute as Maduro cannot be seen to deviate from Chávez's anti-neoliberal positions, for fear of alienating his base (Smilde 2015). Second, Hetland (2016, 17 August) suggests that too many people employed by the state, and, in particular, the military, benefit from the current system, mostly through corruption. Given Maduro's political and institutional weaknesses, he cannot risk alienating the latter group, for fear of their heeding opposition calls for a coup (Hetland 2016, 17 August). Whatever the reasons, the result has been policy paralysis with little real advance in solving the overall socio-economic crisis affecting the Venezuelan people.

The government has, however, made several attempts to respond to the more immediate effects of this crisis. These have included an increased focus on mining, the development of the Comités Locales de Abastecimiento y Producción or CLAPs, as well as the demonetization of the 100 bolivar note and closing of land borders to stem the flow of Venezuelan goods illegally crossing into Colombia. In June, the creation of a new mining ministry officially titled Ministry for the Development of Ecological Mining (Boothroyd-Rojas 2016, 9 June) was emblematic of the former strategy. This was in response to a new US $\$ 4.5$ billion transnational mega-mining project in Bolivar state announced in February, which the government hopes will mitigate the fall in oil revenues (Hetland 2016, 17 August). As Boothroyd-Rojas (2016, 9 June) notes, the government has faced a raft of criticisms from social movements, ecological activists and indigenous groups, who complain they were not consulted regarding the project. A more pointed criticism of this effort is even if it succeeds, it will deepen rather than lessen Venezuela's dependence on extractive industries for trade (Grandin 2016, 16 December; Webber 2016, 18 September; Zibechi 2016).

In April, the government opened numerous CLAPs, which are partnerships between grassroots organizations and the government to provide an alternative food distribution network in all 24 states (Schiavoni and Camcarro 2016, 7 November). The objective of these is to curb the black market and to get food items directly into people's homes at government regulated prices. Though critics argue that the CLAPs suffer from clientelism, favoring households who support the government, the Council on Hemispheric Affairs noted in October that the CLAPs have certainly alleviated some of the shortages, and the frustrations associated with them (COHA 2016, 20 October). Nevertheless, the CLAPs do not overcome the fundamental problem that drives scarcity and shortages, which is a dependency on the export market and the lack of domestic production (Smilde 2016, 5 July). While, in the longer term, CLAPs are intended to engage in local food production and processing, and there are a number 
of initiatives introduced in that direction, these are probably limited in their capacity to overcome shortages in the context of currency and price controls (Schiavoni and Camcarro 2016, 7 November).

In December, Maduro ordered a closing of the border with Colombia in order to prevent the illegal selling of subsidized Venezuelan goods in Colombia. In order to stop the hoarding of the currency in border towns, Maduro also announced that the 100 bolivar note would no longer be legal tender. Citizens were given ten days to exchange the more than six billion notes in circulation, which represented around 50 percent of currency in circulation according to the BBC (2016, 15 February). This caused economic and social turmoil, with protests and looting breaking out in rural border areas. Furthermore, Smilde (2016, 20 December) points to the failure in the move's expressed logic as few would seek "to hoard a currency that lost sixty percent of its value in the past two months" and would instead look to spend it as quickly as possible.

\section{CABINET AND MINISTERIAL RE-SHUFFLES: HIGH EXIT COSTS, CORRUPTION, AND THE MAINTENANCE OF POWER}

The tame efforts by the government to tackle the currency situation were accompanied by changes to important cabinet positions from the end of 2015 through to the beginning of 2017. Following the December 2015 defeat in the National Assembly elections, Maduro called on all ministers to "make their post available to initiate a process of restructuring, renovation and relaunch of the entire national government" (as cited in Holldack 2015, 9 December). In early January 2016, Maduro appointed Luis Salas, a professor from the Bolivarian University of Venezuela, as Vice President for the Economy, as well as head of the newly-created Ministry of Productive Economy. Salas echoed Maduro's views regarding the economic war and the crisis, and was an adherent to the currency and price controls. Ex- businessman Miguel Pérez Abad took the position of Minister of Industry and Commerce, while Jesus Faría was established as the head of the newly commissioned Ministry of Foreign Trade and Investment. However, by early March, Maduro had replaced Luis with the more moderate Pérez Abad. Yet Pérez Abad only remained in this role until early August, dashing hopes for a free float of the Bolivar for which he had tirelessly advocated. Soon thereafter, his replacement, Carlos Faría, suggested that a free float would be highly unlikely (Hetland 2016, 17 August).

Meanwhile, the increasing role of the military in positions of political power has continued in 2016. In August, Maduro appointed General Nestor Reverol as Minister for Interior Justice, days after a U.S. Federal District court issued an indictment against Reverol over allegations of accepting bribes from drugtraffickers between 2008 and 2010. While Maduro highlighted the general's experience as the director of Venezuela's National Anti-Drug Office (ONA) and Commander of the National Guard (Koerner 2016, 3 August), some analysts 
suggest that Reverol's appointment highlights Maduro's unwillingness to tackle corruption in the military (Smilde 2016, 15 August; Hetland 2016, 17 August; Ramsey 2017, 12 January). Indeed, Smilde (2016, 15 August) detects a pattern of Maduro's appointment of military personnel targeted by U.S. sanctions because of criminal accusations. This, he suggests is in order to build a core team whose exit costs are too high to allow them to desert the government, as they would likely face charges in the U.S. if the MUD were to achieve executive power. Three cases illustrate this: in July, Maduro designated General Antonio Benavides Torres as the Chief Commander of the Bolivarian National Guard, while General Gustavo González Lopez was elevated to Minister for Interior Justice, both of whom were subject to U.S. sanctions (Smilde 2016, 15 August). Most notably, in January 2017, Maduro replaced Vice President Aristobulo Istúriz, a long serving member of PSUV governments, with the more radical Tareck El Aissami, placing the latter second in line to the presidency in the event of Maduro's removal. El Aissami has also been linked to drug trafficking by the US - a charge he denies-and was added to the U.S. Treasury's counternarcotics Office of Foreign Assets Control list in February 2017. The appointment of El Aissami would likely be welcomed by the more radical end of the chavista support base, thereby boosting Maduro's legitimacy as the guardian of Chávez's vision for the country. Moreover, The MUD may be less likely to insist on a recall for Maduro as they would not want to see someone even more radical replace him. Also, given the charges of drug-trafficking faced by El Aissami, much like the military personnel appointed to government positions detailed above, he too would face high exit costs if the MUD were to gain control of the executive (Ramsey 2017, 12 January).

Smilde (2016, 15 August) notes that Maduro has cultivated a "loyal core among security officials" that extends beyond those on U.S. blacklists; in July, Defence Minister General Vladimir Padrino López took over as head of the "Grand Supply Mission," thereby taking control of Venezuela's entire food supply system. Since then, the Venezuelan Armed Forces (FANB) have been charged with "regulating food and medicine distribution and overseeing all major ports across the country" (Ramsey 2017, 12 August). In January 2017, the creeping presence of military officials in high-ranking political positions continued, with Maduro designating Air Force Coronel Ramon Celestino Velasquez as Minister of Eco-socialism and Water, and Admiral Cezar Salazar Coll as head of the Ministry of Public Works (Koerner 2017). Both Ramsey (2017, 12 August) and Smilde (2016, 15 August) raise concerns that by allowing the military to oversee food production, Maduro has "made the armed forces a direct stakeholder in the permanence of the regime," whereby military officials have such capacity for economic gain that they would side with the government instead of the people if there is social upheaval (Ramsey 2017, 12 August). Velasco concludes that the real reason behind these decisions may be to "feed the corruption that keeps [the government's] inner core afloat" (Grandin 2016, 16 December). 


\section{THE OPPOSITION'S RESPONSE TO THE CRISIS}

While the government's response to the crisis has been examined in detail, the MUD's response has not received the same attention, particularly in mainstream accounts both journalistic and academic. What have their proposals been, especially as they now dominate at least one arm of government, the National Assembly? Here we will examine a number of MUD policy and strategy documents, including their national party platforms and their strategy for the removal of President Maduro from power. We will also review two laws the Assembly passed but which were referred to the Supreme Court by the President and found unconstitutional: the Amnesty Law that aimed to release and absolve all those imprisoned for violent and other acts aimed at overthrowing the government, and a Housing Law that effectively would have privatized all public housing. First, however, it is necessary to provide a quick review of the characteristics, strategies and objectives of the MUD, in order to help frame the subsequent discussion on the MUD's responses to the crisis.

Cannon (2014) finds that the Venezuelan opposition displayed the following characteristics, strategies and objectives since the beginnings of the Bolivarian period. First, in terms of characteristics, it is both parliamentary and nonparliamentary, with a varying emphasis on each of these parts over time. The MUD coalition was founded in 2008, with about 30 affiliated parties. These vary from the social democratic Podemos, to extreme libertarian groups such as Leopoldo López's Voluntad Popular, to the more mainstream, but neoliberal Primero Justicia and Acción Democratica. Second, strategies varied along three lines: parliamentary, mobilizational and extra-constitutional; that is, respectively, participation in elections, demonstrations and other peaceful protests and, finally, illegal strategies involving violence, including the April 2002 coup, resulting in around 30 deaths, and the La Salida uprising of January / February 2014, which resulted in the deaths of around 44 people. It is this final strategy that seems to predominate now.

Third, while strategies diverged and strategic direction was often a source of tension within the opposition coalition, all shared the same objective- the removal of the government. This remained, in the eyes of all members of the opposition, the principal means by which Venezuela's multiple economic and social problems could be solved. Once the government was removed, a liberal democratic regime and a market-based economy would be (re)installed, both of which are seen as the natural political and economic regimes for the country. Nevertheless, there would be a pronounced emphasis on poverty alleviation, including some elements of continuity with the present Bolivarian regime. Proposals here included the maintenance of the 1999 Constitution, the commitment to keep the state oil company, PDVSA, in public hands, and the continuation of some of the more notable Social Missions to maintain the fight against poverty. 
A clear divergence is evident, however, within the MUD coalition both in terms of political strategy and socio-economic policy. More radical elements, such as Maria Corina Machado, the liberal independent politician, and Leopoldo López's Popular Will party, preferred mobilizational and extra-constitutional means over institutional strategies. Moreover, they advocate a much brusquer "transition" to marketization, including the immediate privatization of all publicly owned enterprises, including PDVSA, as well as, more recently, the drawing up of a new constitution and trials of government ministers (Ellner 2017: 39). In sum, while the MUD is united in its objective of removing the government from power, viewing it as the main cause of the crisis, it remains divided on the means to achieve this and the degree to which the economy and society should be marketized and de-Bolivarianized, and at what pace.

These characteristics, strategies and objectives have remained constant up to and including 2016, as can be seen both in their strategy and policy documents, including legislation passed by the newly MUD-dominated AN. In October 2015 , the

MUD released a short document, entitled "Legislative offer for change" (MUD 2015), outlining their policy platforms for the legislative elections scheduled for the following December. Divided into nine policy areas such as food and other goods shortages, security, incomes for workers and pensioners, public services, housing, corruption and, last but not least, "political prisoners," the opposition articulated three main themes identified in the above account-reintroduction of market mechanisms, poverty alleviation and the removal of the government. For example, market mechanisms are offered as a panacea for the shortages plaguing the country, such as cutting "red tape," reducing taxes, speeding up licenses and permits, and removing any possibility of punishment for hoarding or other practices identified by the government as part of the "economic war," such as expropriations of businesses or other such penalties. Decentralization is suggested for public services, which would be put out to tender to the private sector or funded through strategic partnerships between public and private sector in the form of Public-Private Partnerships (PPI's). Yet it was people's dissatisfaction with the government, rather than market-friendly policies, which allowed the opposition to win so convincingly in the December 2015 legislative elections (Davies 2015, 7 December).

Upon taking office, therefore, the MUD prioritized the removal of the government and the proposal for amnesty for MUD-linked prisoners. On 8 March 2016, two months after the installation of the new Assembly, the MUD released what it called its Hoja de Ruta Democrática (MUD 2016, 13 August) or "Democratic Roadmap" for the removal of Maduro from the presidency. In this document, the MUD set out three parallel strategies to remove the government, in the following order: a "wide national popular mobilisation" demanding the President's resignation; the passing of a Constitutional Amendment "voted for and defended by the people" (although by which means is not specified) to shorten the presidential mandate and hold elections in 2016; and the initiation 
of a Recall Referendum (RR) and passage of a Referendums Law to ensure that this would not be "blocked or held up" (by the government presumably). The delays in the issuing of this document, and the variety of alternatives offered, with the RR coming notably last in the list, reflected the internal divisions within the MUD coalition around the prioritization of the different strategies previously noted (Ellner 2017: 39).

Not long after this, on 30 March, the so-called Amnesty and National Reconciliation Law (Asamblea Nacional 2016a) was passed after a heated debate in the NA. This was introduced to deal with the problem of the oppositiondenominated "political prisoners" — that is individuals jailed by state authorities for organizing and/or participating in violent acts aimed at overthrowing the government, but which the opposition claims were "political" acts and therefore not crimes in the accepted sense and so not subject to established state punishment. The best-known of over 100 such prisoners is the leader of farright libertarian party Voluntad Popular, Leopoldo López. This law, framed by advice to Venezuelans from Pope Francis to embrace "peace, coexistence and dialogue" (Preamble), aimed to grant amnesty for all acts, apart from murder and serious injury, which respond to "a political motivation" (Preamble, point a.), and committed since 1 January, 1999 (the day on which Hugo Chávez assumed power for the first time) until the activation of the law. While the list of crimes specified for amnesty is much too long to relate here, it is worthwhile listing some of the more notable ones (Chapter II, Article 4), including: "property damage" (Art 4: j); "Importation, fabrication, carrying, control of (detentación), provision or hiding of explosive and incendiary artifacts" (Art 4; 1); "use of minors for the commission of crimes" (Art. 4: o); the use of fire to cause common damage (Art. 4: p); treachery (Art. 4: q); rebellion (Art 4: r); encouraging and facilitating rebellion in the armed forces, including the revealing of military secrets (Art. 4: s); illegal carrying of arms and their unauthorized use (Art. 4: v); and, damage to installations of the national grid (Art. 4: w). In article 7, a list is provided of 33 demonstrations, protests and violent uprisings which took place from 2003 until 2014, many of which led to deaths and injuries of citizens and security forces, during which the above listed crimes to be amnestied were committed. Later, some better-known events are listed including the 2002 Coup (Art. 10), the oil strike and lockout carried out in 2002 and 2003 (Art. 11), and the events related to the early 2014 La Salida campaign led by Leopoldo López, (Art. 12), all of which also caused deaths, injuries and severe economic losses. If anything, these lists illustrate the breadth and intensity of the campaign waged by the opposition and opposition-linked groups against the government. As mentioned above, acts of murder and serious injuries are excluded (Chapter 3; Art. 5), as well as crimes against humanity, war crimes and serious offences against human rights perpetrated by the security forces or government (Chapter 1; Art. 3). Nevertheless, there is a clear aim by the opposition to absolve all oppositionlinked groups and activists of any criminal responsibility for these subversive and coercive acts which few governments in the world could possibly accept. 
Unsurprisingly, then, the executive rejected the Amnesty Law, with Maduro charging that it was "a law to protect assassins, criminals, drug dealers and terrorists" (BBC Mundo 2016, 30 March), and referring it to the Supreme Court. In late April, the TSJ declared the law unconstitutional, as it showed "contempt for the life, integrity, and dignity of... those harmed by the amnestied acts, affecting their right to access justice" (Koerner 2016, 22 April). This decision was condemned almost universally by the international media and many international human rights groups, despite the seriousness of the crimes and the persistent attempts to overthrow a series of elected governments, facts which were barely mentioned. ${ }^{3}$ A further example of MUD legislation was the Law to Grant Property Titles to Beneficiaries of the Grand Housing Mission Venezuela (Asamblea Nacional, 2016b). This quite simply aimed to transfer ownership of state housing properties to those currently renting them. This was justified in terms of a Constitutional provision granting citizens the right to a dignified home. This law was again referred by the President to the Supreme Court, which declared it unconstitutional on the grounds that it would eventually benefit the real estate market, rather than the Venezuelan people, thus contravening the social nature of the Housing Mission (TSJ 2016, 6 May).

This quick review of some of the main policies and legislative attempts of the MUD during 2016 demonstrates the following points. First, its policy declarations and some of the laws reviewed here underscore the prioritization of the removal of the government as a response to the crisis, and the continuance of a multi-layered strategy to achieve this, including institutional and mobilizational strategies, as well as seeking amnesty for those who participated in previous illegal strategies. Second, they have demonstrated a continued adherence to marketization of the economy as the prime policy response to the crisis. Both laws also are fundamentally against the founding principles of the Bolivarian Revolution, making agreement on them much more difficult for the government to accept. Hence, rather than achieving peace and dialogue they further deepened the continued struggle between the MUD and the PSUV, now incarnated in a struggle between two state powers (the executive and the legislature). The result has been stalemate. Despite this, however, there were attempts to break this by a third option, that of dialogue.

\section{VII.THE THIRD WAY? 2016'S NATIONAL DIALOGUE PROCESS}

In parallel to the recall process and the street campaigns and protests, a variety of dialogue initiatives between the two sides developed during the year. One was led by three foreign ex- Presidents, Martín Torrijos of Panama, Leonel Fernández of the Dominican Republic, and José Luis Zapatero of Spain, under the auspices of UNASUR. This was further augmented by a series of negotiations facilitated by the Vatican, which began in October, supported by the UNASUR 
mission, that were finally abandoned in February 2017. At the time of writing, there are attempts to revive the process, with, for example, opposition leader and ex-Presidential candidate, Manuel Rosales being released from prison by the government (BBC 2016, 31 December).

Though the proposed national dialogue was initially rejected by leading opposition members, the movement gained traction when the government released four prominent opposition prisoners. While more radical elements, such as Voluntad Popular, rejected the talks, the more mainstream partiesJustice First (PJ), Democratic Action (AD), and A New Era (UNT) - agreed to participate, underlining once again divisions within the coalition around strategy. The MUD, in turn, called off the ongoing AN "trial" of President Maduro and a planned demonstration against the suspension of the recall referendum process. There was also a commitment by both sides to deescalate discourse in order to create a more conducive context for the talks. By 24 October, Ernesto Samper, Secretary General of UNASUR, lauded progress in the talks, including "the generation of trust among political actors" and forging an agenda which included "a Committee on Truth and Justice...the constitutional role of powers, the need to agree on an electoral agenda and immediately adopt important economic measures for social relief" (Samper 2016, 24 October). A Commission of Guarantees was also "proposed in order to seek institutional and permanent solutions to cases that may affect the free exercise of democratic debate" (Samper 2016, 24 October).

The talks eventually led to a five-point agreement between those participating. First, there was a recognition on the part of the opposition of government complaints of "economic war"(meaning actions such as hoarding of key products, contraband etc.) as a source of the crisis. With this admission came promises to cooperate with the government to combat them and to "monitor, tax and control" the acquisition and distribution of goods. There were also promises from the government to work with the CNE to help resolve the problem of the three suspended opposition deputies, and from government and opposition to work together to jointly nominate replacements for two deans on the CNE due to retire in December. They both agreed also to defend Venezuela's rights over the territory of Essequibo in neighbouring Guyana (Boothroyd Rojas 2016, 14 November). A joint statement was released, "Living Together in Peace," reiterating support for peaceful coexistence, "to lead a great national mobilization for agreement, mutual recognition, and peace," among other promises. However, no further meetings were held and the process was officially suspended on 6 December, with the opposition complaining that the government was not keeping to its side of the agreement, such as "the release of so-called 'political prisoners' and a timetable for early presidential elections" (Charles 2017, February). The government, on the other hand, argued that the opposition had not fulfilled their promise to work to stop the "economic war" and to live in peaceful co-existence (Charles 2016, 26 December). 


\section{CONCLUSION}

Velasco argues that Venezuela's economic crisis is the result of a "combination of a haphazard socialist program built atop a foundation of increased oil dependency against the virulent opposition of entrenched elites" (Grandin 2016, 16 December). Our analysis here bears out this diagnosis. First, we have sought to show that government actions have done little to alleviate and much to aggravate the current severe socio-economic crisis affecting Venezuela. Chief among these is their failure to amend the Venezuelan currency regime, which many analysts identify as the root cause for the shortages of food, medicines and other key goods, not to mention its central role in enabling corruption. Second, we have also sought to show that the opposition, while obviously not in the seat of power and therefore in the best position to effect change, have nonetheless prioritized destabilizing actions rather than concrete policy proposals-most particularly mobilizational actions that regularly resulted in violence. When actual policy suggestions did emerge, these were primarily of a market-oriented, neoliberal nature, with little evidence produced as to how these would resolve the situation positively for poorer Venezuelans. Moreover, legislation produced by the MUD-dominated National Assembly had little positive effect and was guaranteed-as with the Amnesty Law and the Housing Law-to antagonize the government further. Most importantly, neither side seems to offer concrete proposals to resolve the country's main underlying problem of continued oil dependency. Divisions in the MUD coalition augur against any improvement here, especially as mobilizational and illegal strategies have once again been prioritized for the moment.

Hence, in conclusion, we argue that both government and opposition must share the blame for the contemporary state of affairs in Venezuela, and, as such, both must play their part in offering a solution to the political and economic crisis. McCoy (2017: 54) contends that despite most Venezuelans wanting dialogue between opposition and government, a polarizing electoral logic has been embedded in the populace. This has led to what she terms a "pernicious polarization" (McCoy 2017: 54) based on a psychologically, spatially, and materially divided population. Perceptions must be altered so that the opposing camp is no longer seen as an enemy to be vanquished, but rather an as an adversary to compete against and negotiate with in order to achieve the collective interest (McCoy 2017). It is therefore necessary to identify the conditions that will be conducive to altering these polarized perceptions, and we believe the main route to this is through dialogue. There are a number of key elements which need to be dealt with to ensure successful dialogue. For the government, whose authoritarian tendencies have crept forward during 2016, and for the higher ranks of the military, exit costs are extremely high, not only in terms of losing power, but also with regard to the risk of imprisonment due to corruption and drug trafficking charges. For the opposition, there is the potential of alienating voters who reject dialogue with what is believed by many 
to be an authoritarian and illegitimate, regime. Both also face high entry costs due to deeply embedded mistrust between the two sides.

In order to move beyond the current impasse, the exit costs for the upper echelons of the government, the PSUV, and the military generals must be lowered, while the entry costs for the opposition to engage in negotiation must also be reduced. It is imperative that an alternative narrative to the polarized logic emerge, showing how both sides can exit the current impasse without facing political annihilation. While it may appear that there are "two camps formed across an impermeable boundary, with mutually exclusive identities and interests" (McCoy 2017: 56), the government and opposition are in fact fragmented. While this fragmentation makes dialogue less efficient, it may offer "more space and flexibility for dialogue across the boundary line and the creation of new coalitions" (McCoy 2017).

In both camps, there are sectors which are more disposed to compromise on these issues of exit and entry costs. These may be more amenable to agreement on issues such as guarantees against charges being pressed on government members for alleged crimes if the PSUV were to lose a general election, and the release of opposition-linked prisoners. This could be achieved, perhaps, as part of a wider Truth Commission, as suggested by UNASUR Secretary General Ernesto Samper. Agreement would also have to be reached on the nature of the socio-economic regime, particularly with regard to distributive and political gains made for popular sectors during the chavista period, as well as the constitutional role of the PSUV. Finally, there would need to be agreement on respecting election results and the makeup of existing institutionality, especially in the electoral and judicial branches. A further important element would be consistent support from international actors for such a process and to help guarantee its results. It may turn out that this scenario is reminiscent of previous pacts, such as that of the 1958 Punto Fijo Pact, which installed the regime replaced by the current Bolivarian Republic and which was regarded as the source of much of today's conflict. The alternative, however, is a context of continuing confrontation and polarization, with unknown outcomes for the peace and stability of the country and the region.

\section{REFERENCES}

Al Jazeera. 2016, 3 November. "Venezuela Suspended from Mercosur." Retrieved on 17 February 2017 from http://www.aljazeera.com/news/2016/12/venezuela-suspended -mercosur-violations-161203035501462.html

Asamblea Nacional. 2016a. "Proyecto de Ley de Amnistía y Reconciliación Nacional." Retrieved on 17 February 2017 from http://www.asambleanacional.gob.ve/uploads / documentos/doc_ed81a6f2079a4d3aeaa5e74710b47c5458f139d6.pdf

Asamblea Nacional. 2016b. "Ley de Otorgamiento de Títulos de Propiedad a Beneficiarios de la Gran Misión Vivienda Venezuela." Retrieved on 13 September, 2017 from https: / / transparencia.org.ve/project/informe-para-la-segunda-discusion-del-proyec- 
to-de-ley-de-otorgamiento-de-titulos-de-propiedad-a-beneficiarios-de-la-gran-mision-vivienda-venezuela/

BBC. 2016, 15 February. "Venezuela Delays 100-Bolivar Banknote Withdrawal." Retrieved on 15 February 2017 from http:/ / www.bbc.com/news/world-latin-america 38355349

BBC Mundo. 2016, 30 March. "La Asamblea Nacional de Venezuela aprueba la ley de amnistía a 'presos políticos." 'Retrieved on 17 February 2017 from http:/ / www.bbc.com/mundo/noticias/2016/03/160329_venezuela_parlamento_ley_am stia_ep

BBC. 2016, 31 December 2016. “Venezuela Releases Opposition Figure Manuel Rosales." BBC News. Retrieved on 27 February 2017 from http://www.bbc.com/news/world latin-america-38479190

BBC Mundo. 2016, 23 August. "Para el secretario general de la OEA, Luis Almagro, llegó el 'final de la democracia en Venezuela'." Retrieved on 17 February 2017 from http:// www.bbc.com/mundo/noticias-america-latina-37162169

Boothroyd-Rojas, Rachael. 2016, 9 June. "Venezuela's Maduro Creates New Ministry for the Development of Ecological Mining." Venezuela Analysis. Retrieved on 17 February from https:/ /venezuelanalysis.com/news/12018

Boothroyd-Rojas, Rachael. 2016, 16 September. "MERCOSUR Blocks Venezuela from Taking Over Presidency." Venezuela Analysis. Retrieved on 17 February 2017 from https:// venezuelanalysis.com/news/12553

Boothroyd-Rojas, Rachael. 2016, 14 November. “Opposition and Government Reach Five Agreements for Continued Dialogue." Venezuela Analysis. Retrieved on 27 February from https:/ / venezuelanalysis.com/news/12782

Buxton, Julia. 2016. "Venezuela after Chávez." Neww Left Review 99 (May-June): 5-25.

Cannon, Barry 2014. "As Clear as MUD: Characteristics, Objectives, and Strategies of the Opposition in Bolivarian Venezuela." Latin American Politics and Society 56(4): 49-70.

Charles, Jeanette. 2016, 26 December. "Venezuelan Opposition Calls off Participation in Dialogue with Government." Venezuela Analysis. Retrieved on 27 February from https: / / venezuelanalysis.com/news/12858

Charles, Jeanette. 2017, 2 February. "Bolivarian Government Calls for 'Second Phase' of Dialogue with Opposition." Venezuela Analysis. Retrieved on 27 February from https:/ / venezuelanalysis.com/news/12922

COHA [Council on Hemispheric Affairs]. 2016, 20 October. "Venezuelans turn to Maduro in Increasing Numbers." Retrieved on 14 February 2017 from http://www.coha.org/ venezuelans-turn-to-maduro-in-increasing-numbers /

Cyr, Jennifer. 2013. “Que veinte años no es nada: Hugo Chávez, las elecciones de 2012 y el continuismo político venezolano." Revista de Ciencia Política 33(1): 375-391.

Davies, Wyre. 2015, 7 December. "Venezuela Elections: Why did Maduro's Socialists Lose?" BBC World. Retrieved on 15 May 2017 from http://www.bbc.com/news/world-latin-america-35025941

El País. 2016, 20 December. “Caos en Venezuela: Urge que Maduro dé un paso al lado y abra un proceso de transición." Retrieved on 17 February 2017 from http:/ / elpais.com/ elpais/2016/12/19/opinion/1482170601_259420.html

Ellner, Steve. 2017. "Venezuela's National Dialogue: Disaggregating Key Issues." LASA Forum XLVIII(1): 39-42.

Emersberger, Joe. 2016, 19 July. "Chavismo Must Stop the Economic Bleeding." TeleSur TV. Retrieved on 17 February 2017 from http://www.telesurtv.net/english/opinion/ Chavismo- Must-Stop-the-Economic Bleeding-20160719-0039.html

Gill, Timothy M. 2016. "Whither Venezuelan Bolivarianism?" NACLA Report on the Americas, 48(4): 367-371.

Gill, Timothy M. 2016, 29 December. "U.S.-Venezuela Relations will Probably Deteriorate under Trump. Ask ExxonMobil Why." The Washington Post. Retrieved on 17 February 2017 From https://www.washingtonpost.com/news/monkey-cage/wp/2016/12/29/u-s -ve nezuela-relations-will-likely-deteriorate-under-trump-ask-exxonmobil-why/?utm_ter$\mathrm{m}=.1 \mathrm{~b} 4 \mathrm{~d} 7 \mathrm{dd} 9 \mathrm{bf} 13$ 
Gill, Timothy M. 2017, 12 January. “Embattled Venezuela Can Still Count on International Lifelines, From Russia to China." World Politics Review. Retrieved on 17 February 2017 from de febrero de 2017 http:/ / www.worldpoliticsreview.com/articles /20895/ embattled-venezuela-can-still -count-on-international-lifelines-from-russia-to-china

Grandin, Greg. 2016, 16 December. "Christmas in Caracas? Worse than the Grinch! Amid Today's Crisis, What Is Salvageable from the Bolivarian Revolution? A Conversation with Alejandro Velasco." The Nation. Retrieved on 15 February 2017 from https:/ / www.thenation.com/article/christmas-in-caracas-worse-than-the-grinch/

Hetland, Gabriel. 2016, 17 August. "Why is Venezuela in Crisis?" The Nation. Retrieved on 10 February 2017 from https: / / www.thenation.com/article/why-is-venezuela-in-crisis /

Holldack, Jonas. 2015, 9 December. "Maduro asks Cabinet to Resign, Plans Restructuring in Face of Electoral Defeat." Venezuela Analysis. Retrieved on 11 February 2017 from https:/ /venezuelanalysis.com/news/11765

INE [Instituto Nacional de Estadística, República Bolivariana de Venezuela]. 2017. Estadísticas. Retrieved on 26 February 2017 from http:/ / www.ine.gov.ve/

Koerner, Lucas. 2016, 3 August. "Venezuela's Maduro Names New Ministers in Cabinet Shakeup." Venezuela Analysis. Retrieved on 11 February 2017 from https:/ / venezuelanalysis.com/news/12117

Koerner, Lucas. 2016, 22 April. "Venezuela's Supreme Court Strikes a Blow to the Impunity of Liberal Terror." Venezuela Analysis. Retrieved on 17 February 2017 from https:/ / venezuelanalysis.com/analysis/11943

Koerner, Lucas. 2017. "Venezuela's Maduro Replaces VP and Top Ministers in Cabinet Shuffle." Venezuela Analysis. Retrieved on 7 January 2017 from https: / / venezuelanalysis. com/news/12869

López Maya, Margarita. 2017. “Cronología de los eventos que condujeron a la suspensión el RRP y la Mesa de Diálogo." LASA Forum XLVIII(1): 47-52.

McCoy, Jennifer. 2017. “Lessons from Venezuela's Pernicious Polarization.” LASA Forum XLVIII(1): 53-57.

MUD. 2015. “Oferta legislativa para el cambio." Retrieved on 17 February 2017 from http: / / www.unidadvenezuela.org/2015/10/oferta-legislativa-para-el-cambio/

MUD. 2016, 3 August. “Unidad Democrática dio a conocer Hoja de Ruta 2016." Retrieved on 17 February 2017 from http:/ / www.unidadvenezuela.org/2016/03/38693/

New York Times. 2016, 17 May. "Venezuela's Downward Spiral." Retrieved on 16 February 2017 from https://www.nytimes.com/2016/05/17/opinion/venezuelas-downward -spiral.html

Pourcelot, Jean Philippe. 2016, 10 March. "Maduro Reshuffles Cabinet and Raises Gasoline Prices." Focus Economics. Retrieved on 12 February 2017 from http:/ / www.focus economics.com/countries/venezuela/news/inflation/maduro-reshuffles-cabinet-and raises-gasoline-prices

Ramsey, Geoff. 2017, 12 January. "Mounting Exit Costs Complicate Change in Venezuela." WOLA Blog. Retrieved on 13 February from https://venezuelablog.org/mounting-exit -costs-complicate-change-in-venezuela/

Reuters 2016, 16 November. "Venezuela: Three Opposition Lawmakers Resign in Concession to Maduro." The Guardian. Retrieved on 15 February 2017 from https:/ /www. theguardian.com/world/2016/nov/16/venezuela-three-opposition-lawmakers-resign-in-concession-to-maduro

Sagarzazu, Iñaki 2014. "Venezuela 2013: un país a dos mitades." Revista de Ciencia Política 34(1): 315-328.

Samper, Ernesto 2016, 24 October. "Statement by the Secretary General of UNASUR, Former President Ernesto Samper Pizano on the Venezuelan Situation." UNASUR Prensa y Relaciones. Retrieved on 27 February 2017 from http://www.unasursg.org/en/ node/994

Sánchez Urribarrí, Raúl A. 2016. "Venezuela (2015): Un régimen híbrido en crisis." Revista de Ciencia Política 36(1): 365-381. 
Santos, Miguel Angel. 2017. “Venezuela: Running on Empty.” LASA Forum XLVIII(1): 5862.

Schiavoni, Christina and William Camacaro. 2016, 7 November. "Hunger in Venezuela? A Look Beyond the Spin." FoodFirst. Retrieved on 11 February 2017 from https:/ / foodfirst.org/special-report-hunger-in-venezuela-a-look-beyond-the-spin/

Smilde, David 2015. "The End of Chavismo?" Current History 114 (769): 49-55.

Smilde, David. 2016, 5 August. "With Blacklisted Officials, Venezuela's Maduro Builds a Cor." WOLA Blog. Retrieved on 14 February 2017 from http:/ / venezuelablog.tumblr.com/ post/148494196139/with-blacklisted-officials -venezuelas- maduro

Smilde, David. 2016, 5 July. "Notes on the Current Context." WOLA Blog. Retrieved on 12 February 2017 from https:/ / venezuelablog.org/notes-on-the-current-context/

Smilde, David. 2016, 20 December. "Why is the Maduro Government Demonetising the Bs. 100 Note?" WOLA Blog. Retrieved on 15 February 2017 from http:/ / venezuelablog.tumblr.com/post/154722117629/why-is-the-maduro -government-demonetizing-the-bs

TSJ [Tribunal Supremo de Justicia de Venezuela]. 2016, 6 May. “Declarada inconstitucional Ley de Otorgamiento de Títulos de Propiedad a Beneficiarios de la Gran Misión Vivienda Venezuela." Noticias TSJ. Retrieved on 27 February 2017 from http:/ / www. tsj.gob.ve/-/ declarada-inconstitucional-ley-de-otorgamiento-de-titulos-de-propiedad-a-beneficiarios-de-la-gran-mision-vivienda-venezuela.

Velasco, Alejandro. 2016, 25 October. "Explaining the Venezuelan Crisis." TRT World. Retrieved on 15 February 2017 from http://www.trtworld.com/opinion/why-is -the-venezuelan-economy-so-prone-to-collapse-213821

Vivanco, José Miguel. 2016, 14 April. "Upholding Abuse in Venezuela." Retrieved on 27 February 2017 from https://www.hrw.org/news/2016/04/14/upholding-abuse-venezuela

Washington Post. 2016, 26 December. "Venezuela is Lurching Closer and Closer to Chaos." Retrieved on 16 February 2017 from https://www.washingtonpost.com/ opinions / global-opinions / venezuela-is-lurching-closer-and-closer-to-chaos/2016/12/26/63af5186-c79c-11e6-bf4b-2c064d32a4bf_story.html

Watts, Jonathan. 2016, 11 October. "Venezuela on the Brink: A Journey Through a Country in Crisis." The Guardian. Retrieved on 16 February 2017 from https:/ /www.theguardian.com/world/2016/oct/11/venezuela-on-the-brink-a-journey -through-a-countryin-crisis

Webber, Jeffrey. 2016, 18 September. "Latin America: From Reform to Resistance (G. Souvlis, Interviewer)." Salvage Zone. Retrieved on 15 September 2017 from http:/ /salvage. zone/online-exclusive/latin-america-from-reform-to-resistance-an-interview-withjeffery-webber-part-1/

Weisbrot, Mark. 2016, 23 October. "Venezuela's Economic Crisis: Does it Mean that the Left Has Failed?" Truth-out.org. Retrieved on 15 February 2017 from http://www.truth out.org/news /item/38094-venezuela-s-economic-crisis-does-it-mean-that-the-lefthas failed

Weisbrot, Mark. 2016, 4 May. “Economic Policy Could Determine the Political Results in Venezuela." The Hill. Retrieved on 16 February 2017 from http://thehill.com/blogs/ pundits-blog/international/278616-economic-policy-could-determine-the-political-results-in

Woody, Christopher 2016, 19 December. "Trump's Secretary of State Pick Could Spell Trouble for one of Latin America's Biggest Oil Producers." Business Insider UK. Retrieved on 17 February 2017 from http://www.businessinsider.com/secretary-state -rex-tillerson-us-venezuela-relations-2016-12

Zibechi, Raúl 2016. "Progressive Fatigue?" NACLA Report on the Americas 48(1): 22-27.

Zuzunaga Ruiz, Roger. 2016, 27 October. "Samper: 'En Unasur hemos apoyado el revocatorio en Venezuela'." El Comercio. Retrieved on 17 February from http:/ / elcomercio.pe/ mundo/latinoamerica/samper-unasur-hemos-apoyado-revocatorio-venezuela-noticia-1942067 
Barry Cannon teaches Politics in the Department of Sociology, Maynooth University, Ireland. He has written extensively on Venezuela including a book, Hugo Chavez and the Bolivarian Revolution (Manchester, 2009) and various journal articles. His latest book is The Right in Latin America: Elite Power, Hegemony and the Struggle for the State (Routledge, 2016).

John Brown is a final year PhD student at the Department of Sociology, Maynooth University, Ireland. A John and Pat Hume, Irish Research Council and Fulbright Scholar, his study centres on democratization processes in contemporary Venezuela and Bolivia, completing field research in both countries as part of his work. 
- 